\section{Humoral Immunological Response in Broilers Vaccinated Against Newcastle Disease and Supplemented with Dietary Zinc and Vitamin E}

Mail Address

ALSP Cardoso

Faculdade de Medicina Veterinária e Zootecnia - USP

Av. Duque de Caxias - Norte, 225

Campus da USP

13.630-970. Pirassununga, SP, Brasil

\section{ABSTRACT}

The humoral immune response of broilers fed diets supplemented with Zinc (Zn) $(0,40$, and $400 \mathrm{mg} / \mathrm{kg})$ and vitamin $E(0,12$, and $120 \mathrm{mg} /$ $\mathrm{kg}$ ), separately or combined, was evaluated. A completely randomized design was used according to a $3 \times 3$ factorial arrangement, with nine treatments and four repetitions per treatment. Sexed birds $(n=1440)$ were distributed in 36 boxes with 40 chicks each and reared until 41 days of age. Vaccination against Newcastle Disease (ND) was performed when birds were 14 days old. ELISA and HI tests were used to assess antibody levels before vaccination and at 28, 35 and 41 days of age. The results were analyzed using Proc Mixed from SAS. The interaction between the highest dietary levels of $\mathrm{Zn}$ and vitamin $\mathrm{E}$ resulted in higher antibody levels in ELISA at 14, 28, 35 and 41 days of age. Increasing levels of $\mathrm{Zn}$ and vitamin $\mathrm{E}$ supplemented separately in the diets provided greater levels of hemagglutinating antibodies in $\mathrm{HI}$ at 14, 28, 35 and 41 days old. The interaction between the highest levels of $\mathrm{Zn}$ and vitamin $\mathrm{E}$ resulted in greater antibody levels at 41 days of age.

\section{INTRODUCTION}

Immunological response might be influenced by several factors. Among them, the nutritional condition of the animal subjected to antigenic challenge has been widely studied, including the effects of zinc and vitamin $\mathrm{E}$.

Vitamin $\mathrm{E}$ acts effectively on the immunological system either by influencing immune cell proliferation (Tengerdy \& Brown, 1977), or by its antioxidant and protective activity on cell membrane integrity.

The National Research Council (NRC) (1994) suggests that vitamin E should be supplemented at $12 \mathrm{mg} / \mathrm{kg}$ in broiler diets throughout rearing. However, higher levels have been used in some studies, as a means of improving immune response (Tengerdy \& Nockels, 1973). On the other hand, vitamin E supplementation has actually improved the responses of the humoral immune system in comparison to the recommended standard levels (Tengerdy \& Brown, 1977).

Zinc is an essential micro-mineral that is involved in several metabolic routes that are fundamental for growing and living (Maiorka \& Macari, 2002). According to NRC (1994), the recommended dietary level is 40ppm for broilers. This mineral is essential for the immunological function and disease prevention, since it improves the responses to antigenic challenges under field conditions (Kidd et al., 1996). Adequate Zn consumption is crucial to the development, maintenance and efficient functioning of the immunological system and the cells associated to it (Dardenne \& Bach, 1993). Nevertheless, previous studies have not proven that zinc has influence on chick immunological response (Kidd et al., 1992; Pimentel \& Cook, 1988; Pimentel et al., 1991). 
Bettger et al. (1980) reported that some diseases associated to $\mathrm{Zn}$ deficiency may be prevented with higher levels of antioxidant in the diets. Besides, vitamin $E$ was the most effective agent against Zn deficiency, evidencing a significant physiologic interaction between vitamin $\mathrm{E}$ and $\mathrm{Zn}$ supplementation in broiler diets.

Cellulites incidence decreased in broilers fed an association of $\mathrm{Zn}$ and vitamin $\mathrm{E}$ (Downs et al., 2000). There was an additive effect between these nutrients and therefore it may be suggested that the interaction may improve broiler performance and humoral immunological response.

The aim of this study was to evaluate the influence of different levels of $\mathrm{Zn}$ and vitamin $\mathrm{E}$ supplementation both separately and combined on broiler humoral immunological response before and after vaccination against Newcastle Disease (ND).

\section{MATERIAL AND METHODS}

In this study, 1440 one-day-old-broiler Hybro chicks were housed in 36 pens with 40 chickens each $50 \%$ males and $50 \%$ females). A completely randomized design was used according to a $3 \times 3$ factorial arrangement, with nine treatments and four repetitions per treatment. Corn- and soybean mealbased diets were formulated according to nutritional levels commonly used in commercial poultry farms. There were three levels of zinc $(0,40$ and $400 \mathrm{mg} / \mathrm{kg}$ ) in the form of chelated zinc, and three levels of vitamin $E(0,12$ and $120 \mathrm{mg} / \mathrm{kg})$ in the form of DL-2-tocopherolacetate. Therefore, nine diets were prepared with the following levels of zinc and vitamin $\mathrm{E}$ per $\mathrm{kg}$ of feed:

1) No zinc or vitamin $E$;

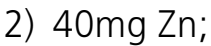

3) $400 \mathrm{mg} \mathrm{Zn}$;

4) $12 \mathrm{mg}$ vitamin $\mathrm{E}$;

5) $40 \mathrm{mg} \mathrm{Zn}$ and $12 \mathrm{mg}$ vitamin $\mathrm{E}$;

6) $400 \mathrm{mg} Z \mathrm{Zn}$ and $12 \mathrm{mg}$ vitamin $\mathrm{E}$;

7) $120 \mathrm{mg}$ vitamin $\mathrm{E}$;

8) $40 \mathrm{mg} \mathrm{Zn}$ and $120 \mathrm{mg}$ vitamin $\mathrm{E}$; and

9) $400 \mathrm{mg} \mathrm{Zn}$ and $120 \mathrm{mg}$ vitamin E. All birds were supplemented until 41 days of age.

At 14 days old, the chickens were vaccinated using the eyedrop technique against Newcastle disease, using a commercially available LaSota strain. Before vaccination, blood samples were randomly collected by heart puncture from five broilers per repetition. At the 21, 35 and 41 days of age, blood samples were randomly collected from the ulnar vein of ten fowls from each repetition. Serum samples were separated and stored at $-20^{\circ} \mathrm{C}$ for further analyses.

Newcastle antibody levels in serum samples were analyzed using hemmaglutination inhibition ( $\mathrm{HI})$ according to Cunningham (1971) and enzyme-linked immunosorbent assay (ELISA) using a commercial kit according to the instructions provided by the manufacturer (Idexx Laboratories). The antibody levels were expressed as Geometric Mean Titers (GMT) and statistically analyzed using SAS ${ }^{\circledR}$ (SAS Institute, 2000). The hypothesis of the analysis of variance was tested using the LAB ProcMixed procedure of SAS. A polynomial regression analysis was then performed at $5 \%$ of significance level.

\section{RESULTS}

The results of antibody levels in the sera of broilers (GMT) obtained in ELISA and HI are shown in Tables 1 and 2, respectively. In both tests, antibody levels in all samples were significantly affected $(p<0.05)$ by both $\mathrm{Zn}$ and vitamin $\mathrm{E}$, and also by the combination between them.

\begin{tabular}{|c|c|c|c|c|c|}
\hline & & \\
\hline & & \multicolumn{2}{|c|}{$\begin{array}{l}\text { Table } \mathbf{1} \text { - Geometric } \\
\text { the Newcastle Diseas } \\
\text { broilers at 14, 28, } 35 \\
\text { Vitamin E Zinc } \\
\text { (mq/kq) (mq/kq) }\end{array}$} & 35 & 41 \\
\hline & & 196.75 & 1627.50 & 2205.25 & 2075.25 \\
\hline \multirow[t]{3}{*}{0} & 40 & 215.25 & 1902.75 & 2398.50 & 2122.00 \\
\hline & 400 & 279.75 & 2284.00 & 3120.50 & 2822.50 \\
\hline & 0 & 223.00 & 2172.00 & 3108.75 & 2789.00 \\
\hline \multirow[t]{3}{*}{12} & 40 & 234.25 & 2217.00 & 3189.75 & 2804.75 \\
\hline & 400 & 295.75 & 2301.25 & 3383.75 & 2890.25 \\
\hline & 0 & 298.00 & 2351.25 & 3449.75 & 3037.50 \\
\hline \multirow[t]{2}{*}{120} & 40 & 311.00 & 2692.75 & 4220.25 & 3401.50 \\
\hline & 400 & 316.00 & 2785.00 & 4320.00 & 3792.00 \\
\hline SEM & & 6.86 & 41.70 & 33.56 & 39.10 \\
\hline CV (\%) & & 5.21 & 3.69 & 2.06 & 2.74 \\
\hline
\end{tabular}

$\mathrm{SEM}=$ standard error of the mean, $\mathrm{CV}=$ coefficient of variation.

Table 2 - Geometric Mean Titers (GMT) of antibodies against the Newcastle Disease Virus assessed by $\mathrm{HI}$ in the serum of broilers at $14,28,35$ and 41 days of age.

\begin{tabular}{|c|c|c|c|c|c|}
\hline \multirow{2}{*}{$\begin{array}{l}\text { Vitamin } \\
(\mathrm{mg} / \mathrm{kg})\end{array}$} & \multirow{2}{*}{$\begin{array}{c}\text { Zinc } \\
(\mathrm{mg} / \mathrm{kg})\end{array}$} & \multicolumn{4}{|c|}{ GMT (HI) Broilers age (days) } \\
\hline & & 14 & 28 & 35 & 41 \\
\hline & 0 & 2.29 & 39.53 & 65.38 & 55.91 \\
\hline \multirow[t]{3}{*}{0} & 40 & 2.46 & 41.66 & 68.85 & 60.78 \\
\hline & 400 & 2.73 & 49.50 & 92.24 & 81.87 \\
\hline & 0 & 2.59 & 44.41 & 77.56 & 64.23 \\
\hline \multirow[t]{3}{*}{12} & 40 & 2.63 & 49.77 & 90.61 & 80.40 \\
\hline & 400 & 2.83 & 55.78 & 95.73 & 85.96 \\
\hline & 0 & 2.94 & 57.71 & 109.69 & 92.24 \\
\hline \multirow[t]{2}{*}{120} & 40 & 3.04 & 67.53 & 121.57 & 100.61 \\
\hline & 400 & 3.16 & 70.08 & 130.45 & 109.56 \\
\hline SEM & & 0.15 & 3.27 & 3.49 & 2.62 \\
\hline CV (\%) & & 11.27 & 12.39 & 7.39 & 6.45 \\
\hline
\end{tabular}

$\mathrm{SEM}=$ standard error of the mean, $\mathrm{CV}=$ coefficient of variation. 


\section{ELISA Test}

At 14 days, there was a marked linear increase on mean antibody levels with increasing levels of $\mathrm{Zn}$, at 0 and $12 \mathrm{mg} / \mathrm{kg}$ of vitamin $\mathrm{E}$, according to the following equations:

GMT $=0.196 x+201.79\left(R^{2}=0.98\right)$ and

GMT $=0.1775 x+224.97\left(R^{2}=0.99\right)$, respectively, in which the independent variable is zinc level. However, mean antibody levels did not change considerably at $120 \mathrm{mg} / \mathrm{kg}$ of vitamin $\mathrm{E}$. A significant linear increase occurred on antibody levels due to increasing levels of vitamin E within all levels of Zn (0, 40 and $400 \mathrm{mg} / \mathrm{kg})$, according to the following equations:

$G M T=0.7847 x+204.72\left(R^{2}=0.97\right)$;

$G M T=0.7621 x+220.05\left(R^{2}=0.99\right)$, and

$G M T=0.2568 x+285.87 \quad\left(R^{2}=0.87\right)$, where $X$ corresponds to the levels of vitamin $\mathrm{E}$.

At 28 days, mean antibody levels showed a significant increase due to increasing levels of zinc within each vitamin E level. Antibody levels varied according to the following equations at 0,12 and 120 $\mathrm{mg} / \mathrm{kg}$ of vitamin $\mathrm{E}$, respectively:

$\mathrm{GMT}=1.4109 \mathrm{x}+1731.1\left(\mathrm{R}^{2}=0.89\right)$,

GMT $=0.2879 x+2187.9\left(R^{2}=0.93\right)$, and

$G M T=0.7568 x+2498.7\left(R^{2}=0.53\right)$, in which $X$ correspond to the different $Z n$ levels. For 0,40 and $400 \mathrm{mg} / \mathrm{kg}$ of $\mathrm{Zn}$, there was a significant linear increase in the responses of antibody levels with the different levels of vitamin $\mathrm{E}$ based on the following equations:

$\mathrm{GMT}=4.3019 \mathrm{x}+1861\left(\mathrm{R}^{2}=0.57\right)$

GMT $=5.7216 x+2019.1\left(R^{2}=0.90\right)$, and

$G M T=4.2953 x+2267.8\left(R^{2}=0.99\right)$, respectively, in which $X$ is the level of vitamin $E$.

At 35 days, there was a marked increase in antibody levels due to increasing amounts of $\mathrm{Zn}$, within each vitamin $\mathrm{E}$ level. At 0,12 and $120 \mathrm{mg} / \mathrm{kg}$ of vitamin $\mathrm{E}$, behavior is shown by the equations:

$\mathrm{GMT}=2.1763 \mathrm{x}+2255.6\left(\mathrm{R}^{2}=0.99\right)$,

GMT $=0.6287 x+3135.2\left(R^{2}=0.96\right)$, and

$G M T=1.4246 x+3787.7\left(R^{2}=0.43\right)$, respectively, in which $X$ represents $Z n$ levels. At 0, 40 and $400 \mathrm{mg} / \mathrm{kg}$ of $\mathrm{Zn}$, there was a significant linear rise in antibody response at increasing levels of vitamin $E(X)$ that may be expressed according to the following equations:

GMT $=7.5172 x+2590.5\left(R^{2}=0.60\right)$,

GMT $=12.95 x+2699.7\left(R^{2}=0.88\right)$, and

$G M T=9.4709 x+3191.4\left(R^{2}=0.99\right)$, respectively.

At 41 days of age, increasing levels of $Z n(X)$ resulted in a significant linear rise on mean antibody level at 0 , 12 and $120 \mathrm{mg} / \mathrm{kg}$ of vitamin $\mathrm{E}$, according to the equations:
$\mathrm{GMT}=1.8989 \mathrm{x}+2061.4(\mathrm{R}=0.99)$,

GMT $=0.2469 x+2791.8\left(R^{2}=0.99\right)$, and

GMT $=1.5692 x+3180.2\left(R^{2}=0.84\right)$, respectively. For 0,40 and $400 \mathrm{mg} / \mathrm{kg}$ of $\mathrm{Zn}$, there was a significant linear rise in antibody levels with the increase in vitamin $E$, which were expressed by the equations:

$\mathrm{GMT}=5,7568 \mathrm{x}+2380,6\left(\mathrm{R}^{2}=0,58\right)$,

GMT $=8,6303 x+2396,4\left(R^{2}=0,79\right)$, and

$G M T=8,1861 x+2808,1 \quad\left(R^{2}=0,99\right)$, respectively.

\section{HI Test}

At 14, 28 and 35 days of age, zinc and vitamin $E$ interaction had no significant effects on the mean antibody level. At 14 days, antibody levels increased significantly with vitamin $\mathrm{E}$ supplementation $(0,12$ and $120 \mathrm{mg} / \mathrm{kg}$ ), according to the linear regression: $G M T=0.0041 x+2.5595\left(R^{2}=0.35\right)$. Zinc given separately $(0,40$ and $400 \mathrm{mg} / \mathrm{kg})$ had no effect on antibody levels.

In 28-day-old broilers, vitamin $\mathrm{E}$ and zinc supplemented separately increased antibody titers significantly according to:

$\mathrm{GMT}=0.1639 x+45.672(\mathrm{R} 2=0.57)$ and

$G M T=0.023 x+49.513\left(R^{2}=0.13\right)$, respectively.

Antibody levels increased at 35 days with higher vitamin $\mathrm{E}$ and $\mathrm{Zn}$ levels separately, following the quadratic equations, respectively:

$G M T=0.3465 x+79.43\left(R^{2}=0.71\right)$, and

GMT $=0.0468 x+87.806\left(R^{2}=0.15\right)$.

Table 3 presents the mean antibody levels at each evaluation day calculated using the regression analyses of zinc and vitamin E separately.

\begin{tabular}{|c|c|c|c|}
\hline \multicolumn{4}{|c|}{$\begin{array}{l}\text { Table } 3 \text { - Levels of hemmaglutination inhibiting an } \\
\text { expressed as Geometric Mean Titers (GMT). Resu } \\
\text { obtained by regression analysis of } \mathrm{Zn} \text { and vitamin } \\
\text { separately, at the indicated ages. } \\
\text { GMT (HI) Age (days) }\end{array}$} \\
\hline & 14 & 28 & 35 \\
\hline \multicolumn{4}{|c|}{ Vit E (mg/kg) } \\
\hline 0 & $2.49(\mathrm{~L})$ & $43.56(L)$ & $75.49(\mathrm{~L})$ \\
\hline 12 & $2.68(\mathrm{~L})$ & $49.98(\mathrm{~L})$ & $87.97(\mathrm{~L})$ \\
\hline 120 & $3.05(L)$ & $65.10(\mathrm{~L})$ & $120.58(\mathrm{~L})$ \\
\hline \multicolumn{4}{|c|}{ Zinc $(\mathrm{mg} / \mathrm{kg})$} \\
\hline 0 & 2.61 (NS) & $47.21(\mathrm{~L})$ & $84.21(\mathrm{~L})$ \\
\hline 40 & 2.71 (NS) & $52.98(\mathrm{~L})$ & $93.67(\mathrm{~L})$ \\
\hline 400 & 2.91 (NS) & $58.45(\mathrm{~L})$ & $106.14(\mathrm{~L})$ \\
\hline Mean & 2.74 & 52.88 & 94.67 \\
\hline SEM & 0.051 & 1.092 & 1.166 \\
\hline
\end{tabular}

SEM = average standard error; $C V=$ coefficient of variation; $(\mathrm{L})=$ linear model; NS = non significant.

At 41 days of age, mean antibody levels increased significantly from 0 to $120 \mathrm{mg} / \mathrm{kg}$ of vitamin $\mathrm{E}$, which depended on $\mathrm{Zn}$ isolated levels $(\mathrm{X})$, according to the equations: 
$G M T=0.0624 x+57.035\left(R^{2}=0.92\right)$,

GMT $=0.0389 x+71.152\left(R^{2}=0.58\right)$, and

$G M T=0.036 x+95.518\left(R^{2}=0.88\right)$, respectively. Mean antibody levels showed a significant increase with higher vitamin $E$ levels within each $Z n$ level. For 0,40 and $400 \mathrm{mg} / \mathrm{kg}$ of $\mathrm{Zn}$, mean antibody response increased linearly and significantly:

$G M T=0.2856 x+58.228\left(R^{2}=0.98\right)$,

$G M T=0.2746 x+68.513\left(R^{2}=0.83\right)$, and

$G M T=0.2259 x+82.523\left(R^{2}=0.99\right)$, respectively, in which vitamin $E$ levels are the independent variable $X$.

\section{DISCUSSION}

The antibodies detected by $\mathrm{HI}$ and ELISA at 14 days are probably maternal antibodies that were still present in chick serum. Although the levels were statistically different, they were probably not enough to confer protection on broilers. Therefore, it might be supposed that higher levels of $\mathrm{Zn}$ and vitamin $\mathrm{E}$ delay the decrease in the maternal antibody levels.

Improved immunological response was observed at 28, 35 and 41 days old by HI. At 41 days, the interaction between $\mathrm{Zn}$ and vitamin E significantly affected antibody levels. Besides, zinc and vitamin E affected antibody levels individually in 28- and 35-day-old birds; antibody levels increased with increments in supplementation.

The increase in mean antibody levels was noticed by ELISA in the serum of 28-, 35- and 41-day-old birds. Besides, humoral immunological response was improved with higher levels of zinc and vitamin E both individually and in combination, except at the greater vitamin E level combined with zinc supplementation.

According to Paulillo et al. (1987), maximum levels of hemaglutination inhibiting antibodies were seen 21 days after vaccination. This result is corroborated by the present findings, since the highest antibody levels were detected in ELISA in the sera of 35-day-old birds, i.e., 21 days post vaccination.

Broilers supplemented with $132 \mathrm{mg} / \mathrm{kg}$ of vitamin $\mathrm{E}$ in the diet showed improved humoral response than the control group (Tengerdy \& Nockels, 1973). On the other hand, birds fed selenium and vitamin $E$ supplemented to the diet at the levels of $0.06 \mathrm{mg} / \mathrm{kg}$ and $150 \mathrm{lU} / \mathrm{kg}$, respectively, showed significantly higher antibody levels against ND virus ten days after immunization, both in ELISA and $\mathrm{HI}$ (Swain et al., 2000).

Leshchinsky \& Klasing (2001) have reported that the effects of vitamin $E$ on antibody production depends on antibody function. Different levels of vitamin $E$ were fed to broilers $(0,10,25,50,100$ and $200 \mathrm{IU} / \mathrm{kg}$ diet) and the humoral response against red blood sheep cells, infectious bronchitis virus and Brucella abortus was evaluated. The levels of antibodies against the infectious bronchitis virus and red blood sheep cells were higher in broilers fed diets supplemented with vitamin $\mathrm{E}$ at 25 and $50 \mathrm{lU} / \mathrm{kg}$ feed, respectively. The levels of Brucella abortus antibodies were not influenced by vitamin E supplementation.

Several studies have not shown better resistance against diseases, or immunocompetence, as a result of diet supplementation. It has been reported that broilers fed 100 or $250 \mathrm{IU}$ vitamin $\mathrm{E}$ in the diet showed no differences in antibody production (Qureshi et al., 1993).

Antibody production was impaired in broilers with zinc deficiency (Burns, 1983), while zinc supplementation at $8 \mathrm{mg} / \mathrm{kg}$ of diet had no effects on the immunological response of young broilers (Pimentel \& Cook, 1988).

Pimentel et al. (1991) assessed the immunological response in chicks that were fed a diet containing zinc oxide and zinc methionine. It was used the levels of 8 , $18,28,38,48$ and $58 \mathrm{mg} / \mathrm{kg}$ of zinc oxide, and 28,38 , $48,58,68,78$ and $88 \mathrm{mg} / \mathrm{kg}$ of zinc methionine. Neither zinc source nor zinc levels affected the immune response as measured by antibody response against red blood sheep cells. These results corroborate findings reported by Kidd et al. (1992), who supplemented the basal diet $(72 \mathrm{mg} / \mathrm{kg}$ of $\mathrm{Zn})$ with $80 \mathrm{mg} / \mathrm{kg}$ of zinc oxide or zinc-methionine. The immune response in young broilers supplemented with different levels of zinc oxide and zinc-methionine was evaluated and showed no effects of zinc level or source on the levels of red blood sheep cells. However, the group fed with $\mathrm{Zn}$ methionine showed improved humoral immunological response against Salmonella pullorum. Kidd et al. (1993) noticed that chicks originating from breeders fed higher levels of complex Zn showed better immunological response.

\section{CONCLUSION}

The interaction between the highest levels of $\mathrm{Zn}$ and vitamin $\mathrm{E}$ affected the humoral immunological response of broilers and caused a significant increase in GMT in the ELISA test.

In regard to $\mathrm{HI}$ results, response to immunization was improved by the highest levels of zinc or vitamin $E$ used individually in 28- and 35-day-old birds, and also by the combination of the highest levels of these minerals in 41-day-old birds. 


\section{REFERENCES}

Bettger WJ, Reeves PG, Savage JE, O'Dell BL. Interaction of zinc and vitamin $\mathrm{E}$ in the chick. Proceedings of the Society for Experimental Biology and Medicine 1980; 163(3):p.432-436

Burns RB. Antibody production supressed in the domestic fowl by zinc deficiency. Avian Pathology 1983; 12(1):141-142.

Cunningham CH. virologia practica. 6th ed. Zaragoza: Acribia; 1971. $260 p$.

Dardenne M, Bach JM. Rationale for the mechanism of zinc interaction in the immune system. In: Cunningham-Rundles $S$, editor. Nutrient modulation of the immune response. New York: Marcel Dekker; 1993. p. 501-509

Downs KM, Hess JB, Macklin KS, Norton RA. Dietary zinc complexes and vitamin $E$ reducing cellulitis incidence in broilers. Journal of Applied Poultry Research 2000; 9(3):319-323.

Kidd MT, Anthony NB, Lee SR. Progeny performance when dams and chicks are fed supplemental zinc. Poultry Science 1992; 71(7):1201-1206.

Kidd MT, Anthony NB, Newberry LA, Lee SR. Effect of supplemental zinc in either a corn-soybean or a milo and corn-soybean meal diet on the performance of young broiler breeders and their progeny. Poultry Science 1993; 72(8):1492-1499.

Kidd MT, Ferket PR, Qureshi MA. Zinc metabolism with special reference to its role in immunity. World's Poultry Science Journal 1996; 52:309-324.

Leshchinsky TV, Klasing KC. Relationship between the level of dietary vitamin $\mathrm{E}$ and immune response of broiler chickens. Poultry Science 2001; 80(11):1590-1599.

Maiorka A, Macari M. Absorção de minerais. In: MACARI, M.; FURLAN, R. L.; GONZALES, E, editor. Fisiologia aviária aplicada a frangos de corte. Jaboticabal: Funep/Unesp; 2002. 375 p.

National Research Council. Nutrient requirements of poultry. 9th ed. Washington, DC: National Academic Press; 1994. 155 p.

Paulillo AC, Berchieri Jr A, Richtzenhain LJ, Barbosa JC, Montasier HJ, Ariki J, Nakaghi LOS, Quintana JL. Ensaio experimental de diferentes vias de vacinação com a estirpe lentogênica Lasota em frangos de corte: doença de newcastle. Ars Veterinária 1987; 3(1): 73-79.

Pimentel JL, Cook ME, Greger JL. Research note: biovailability of zinc-methionine for chicks. Poultry Science 1991; 70(7):1637-1639.

Pimentel JL, Cook ME. Influence of zinc deficiency on the immune response of the chick. Poultry Science 1988; 67(suppl 1):139.

Qureshi MA, Ferket PR, Garlich JD. Effect of dietary supplementation of vitamin $E$ on the immune function of turkey poults [abstracts]. Poultry Science 1993; 72(suppl 1): 56. SAS ${ }^{\circledR}$. User's guide: statistics. version 8. SAS Institute: Cary; 2000.
Swain BK, Johri TS, Majumdar S. Effect of supplementation of vitamin $E$, selenium and their different combinations on the performance and immune response of broilers. British Poultry Science 2000; 41(3):287-292.

Tengerdy RP, Brown JC. Effect of vitamin E and A on humoral immunity and phagocytosis in E. coli infected chicken. Poultry Science 1977; 56(3):957-963.

Tengerdy RP, Nockels CF. The effect of vitamin E on egg production, hatchability and humoral immune response of chickens. Poultry Science 1973; 52(2):778-783. 


\section{FACTA}

\section{PUBLICAÇÕES FACTA}

Anais da Conferência APINCO'94

Anais da Conferência APINCO'95

Anais da Conferência APINCO'97

Anais da Conferência APINCO'98

Anais da Conferência APINCO'99 (2 vol)

Anais da Conferência APINCO'00 (2 vol)

Anais da Conferência APINCO'02 (1 vol)

Anais da Conferência APINCO'03 (1 vol)

Anais da Conferência APINCO'05 (2 vol)

Anais da Conferência APINCO'06 (1 vol)

II Simpósio Internacional de Coccidiose Aviária

Col. FACTA - Manejo de Frangos

Il Simpósio da Doença de Gumboro

Simpósio FACTA de Postura Comercial

Doença das Aves

Fisiologia Aviária

Manejo da Incubação

Produção de Frangos de Corte

Manejo de Matrizes de Corte

Para maiores informações:

facta@facta.org.br ou Fone: (19) 3243-6555 